Published in final edited form as:

Neuropharmacology. 2013 June ; 69: 16-24. doi:10.1016/j.neuropharm.2012.04.004.

\title{
The role of inflammation in epileptogenesis
}

\author{
Annamaria Vezzani ${ }^{1}$, Alon Friedman ${ }^{2}$, and Raymond J. Dingledine ${ }^{3}$ \\ ${ }^{1}$ Department of Neuroscience, Mario Negri Institute for Pharmacological research, Milano, Italy \\ ${ }^{2}$ Department of Physiology and Neurobiology and Biomedical Engineering, Faculty of Health \\ Sciences and Zlotowski Center for Neuroscience, Ben-Gurion University of the Negev, Israel \\ ${ }^{3}$ Department of Pharmacology, Emory University School of Medicine, Atlanta, GA, USA
}

\section{Summary}

One compelling challenge in the therapy of epilepsy is to develop anti-epileptogenic drugs with an impact on the disease progression. The search for novel targets has focused recently on brain inflammation since this phenomenon appears to be an integral part of the diseased hyperexcitable brain tissue from which spontaneous and recurrent seizures originate. Although the contribution of specific proinflammatory pathways to the mechanism of ictogenesis in epileptic tissue has been demonstrated in experimental models, the role of these pathways in epileptogenesis is still under evaluation. We review the evidence conceptually supporting the involvement of brain inflammation and the associated blood-brain barrier damage in epileptogenesis, and describe the available pharmacological evidence where post-injury intervention with anti-inflammatory drugs has been attempted. Our review will focus on three main inflammatory pathways, namely the IL-1 receptor/Toll-like receptor signalling, COX-2 and the TGF- $\beta$ signalling. The mechanisms underlying neuronal-glia network dysfunctions induced by brain inflammation are also discussed, highlighting novel neuromodulatory effects of classical inflammatory mediators such as cytokines and prostaglandins.

The increase in knowledge about a role of inflammation in disease progression, may prompt the use of specific anti-inflammatory drugs for developing disease-modifying treatments.

\section{Introduction}

In the last decade, evidence from clinical and experimental studies indicates that brain inflammation is an intrinsic feature of the hyperexcitable pathologic brain tissue in pharmacoresistant epilepsies of differing etiology (Vezzani et al., 2011b). Moreover, pharmacological studies in seizure models, and the assessment of seizure susceptibility in genetically modified mice with perturbed inflammatory signalling, demonstrate that brain inflammation is not a mere epiphenomenon of the pathologic tissue. Rather, brain inflammation contributes significantly to determine seizure threshold in susceptible brain regions, thus playing a role in seizure precipitation and their recurrence (Dubé et al., 2005; Kulkarni and Dhir, 2009; Riazi et al., 2010; Vezzani et al., 2011b; Vezzani et al., 2011d). Various in vitro and in vivo findings also suggest that specific sets of inflammatory

(C) 2012 Elsevier Ltd. All rights reserved.

Correspondence to: Annamaria Vezzani, Laboratory Experimental Neurology, Deptartment of Neuroscience, Mario Negri Institute for Pharmacological Research, Via G. La Masa 19, 20156 Milano, Italy, Tel +39-02-39014410, Fax +39-02-3546277, vezzani@marionegri.

Publisher's Disclaimer: This is a PDF file of an unedited manuscript that has been accepted for publication. As a service to our customers we are providing this early version of the manuscript. The manuscript will undergo copyediting, typesetting, and review of the resulting proof before it is published in its final citable form. Please note that during the production process errors may be discovered which could affect the content, and all legal disclaimers that apply to the journal pertain. 
molecules and their cognate receptors, when expressed in a permissive tissue environment, can mediate neuronal cell loss and contribute to the associated molecular and synaptic plasticity. These effects are shared by molecules acting as endogenous activators of the IL-1 Receptor/Toll-like receptor (IL-1R/TLR) or the Transforming Growth Factor (TGF)- $\beta$ signalling, and by the products of the COX-2 pathway activation. More limited information is available on the physiopathological effects of other molecules of the inflammatory cascade that are upregulated in epileptic tissue, e.g. proinflammatory cytokines such as IL-6 and TNF-a, the tissue plasminogen activator, the membrane attack complex of the complement system, and the vasoactive endothelial growth factor (VEGF) (Croll et al., 2004; Ravizza et al., 2010).

Inflammatory processes are not only present in chronic epileptic brain but some of these pathways are also upregulated following an epileptogenic injury, and they often persist during the latent phase that precedes spontaneous recurrent seizures. This evidence has generated the testable hypothesis that brain inflammation, in addition to its established contribution to ictogenesis, may play a role in the development of the epileptogenic process. Studies related to the role of brain inflammation in epileptogenesis are still in their infancy, however there is available pharmacological evidence to support this role (Ravizza et al., 2011). One set of evidence also shows long-term increase in brain excitability in mice overexpressing cytokines in astroglia (Akassoglou et al., 1997; Campbell et al., 1993; Stalder et al., 1998), or in rodent brain after the induction of an inflammatory challenge, particularly if this event occurs during the early post-natal life (Riazi et al., 2010).

We describe here some of the experimental evidence that conceptually supports a role of brain inflammation in epileptogenesis by focusing on three main pathways, namely the Interleukin (IL)-1 receptor (R)/Toll-like receptor (TLR), Transforming Growth Factor (TGF)- $\beta$ and Cyclooxygenase-2 (COX-2) signaling. We will also present the pharmacological data obtained by targeting these systems in epileptogenesis models. Finally, we will address the usefulness of biomarkers of brain inflammation for prognostic and therapeutic purposes in symptomatic epilepsies, and will discuss the possibility that antiinflammatory post-injury intervention may be of value for delaying or arresting the epileptic process.

\section{Tissue inflammation and outcome determinants}

Inflammation is regarded as an homeostatic mechanism induced in tissue by infection or injury in order to remove the specific pathogen or for tissue repair. It consists of the induction of an array of inflammatory molecules, classically initiated by the activation of innate immunity mechanisms. In some circumstances, inflammation can become detrimental for tissue resulting in cell dysfunction or death. The pathologic outcome of tissue inflammation has been well documented in autoinflammatory and autoimmune diseases, and more recently brain inflammation has gained recognition as a crucial contributor to the etiopathogenesis of several CNS disorders, including epilepsy (Vezzani et al., 2011b).

The tissue key determinants of the beneficial vs pathologic outcomes of inflammation are not yet fully elucidated. However, there is consensus on at least three pivotal aspects, namely the extent of inflammation and time tissue is exposed to inflammation (which are both determined by the severity of the primary tissue insult and other genetic and epigenetic factors), and the microenvironment which includes the sources of inflammatory molecules, the target cells which express the relevant cognate receptors for inflammatory signalling activation, and primarily the action of anti-inflammatory molecules. Anti-inflammatory mechanisms are instrumental for controlling both the extent and the duration of tissue inflammation; they govern the resolution of the inflammatory processes, thus preventing the 
occurrence of detrimental effects associated with chronic inflammation. Noteworthy, brain inflammation induced by an epileptogenic injury has a rapid onset $(<30 \mathrm{~min})$, it can persist for several days thus outlasting the initial precipitating event, and it is inefficiently opposed by endogenous anti-inflammatory mechanisms. In particular, IL-1 receptor antagonist (IL-1ra) an endogenous competitive antagonist of IL-1 $\beta$ is inefficiently synthetized during brain inflammation ignited by seizures (De Simoni et al., 2000; Oprica et al., 2003), and the same holds true for CD59, a molecule instrumental for controlling the complement cascade activation (Aronica et al., 2007). Following a convulsant challenge or an epileptogenic brain injury, cytokines, prostaglandins and other downstream inflammatory molecules together with their receptors are induced in neurons and activated glial cells, as well as in endothelial cells of the blood-brain barrier (BBB), in the brain region of focal injury. This phenomenon begs the question of the functional consequences that the activation of inflammatory signallings may have for brain tissue physiology.

\section{Role of inflammation in altered neuronal excitability}

Although cytokines and downstream mediators of the inflammatory cascade are considered as an integral part of innate and adaptive immunity activation in the periphery, it is now clear that these inflammatory molecules can also subserve non-conventional neuromodulatory functions in CNS by acting directly or indirectly on neurons, and affecting their excitability threshold at cellular and network levels.

\section{IL-1/TLR signalling}

This signalling is pivotally involved in the initiation of tissue inflammation since it is the upstream activator of innate immunity, the first immune system to be induced by tissue injury or following a large variety of biological stressors. The expression and function of IL-1R/TLR signalling was originally described in lymphoid tissues; however, this signalling has been identified also in brain where it produces various physiopathological effects. In particular, IL-1R1, TLR2, TLR3 and TLR4 are expressed by microglia, astrocytes and neurons. Expression of these receptors has been demonstrated also in ependymal cells of the cerebral ventricles and in the endothelial cells of the BBB (Ban et al., 1991; Chakravarty and Herkenham, 2005; Ravizza and Vezzani, 2006; Takao et al., 1990; Turrin and Rivest, 2004). In vivo IL-1R1 or TLRs are expressed at low levels in brain cells under physiological conditions but these receptors can be rapidly upregulated in various pathological conditions, including cell injury and seizures (Allan et al., 2005; Ericsson et al., 1995; Maroso et al., 2010; Peltier et al., 2010; Ravizza and Vezzani, 2006; Turrin and Rivest, 2004; Zurolo et al., 2011). Notably, the functional outcome of the activation of IL-1R/TLR signalling in brain highly depends on the type of cell expressing these receptors (Vezzani et al., 2011d). Recent evidence demonstrates a functional link between the activation of IL-1R1, TLR4 and TLR3 and rapid changes in neuronal excitability: in the hippocampus, IL- $1 \beta$ and lipopolysaccharide (LPS), a component of gram negative bacterial wall and prototypical activator of TLR4, can both induce rapid changes in synaptic transmission, and affect LTP via activation of a specific set of kinases (e.g. JNK, P38 MAPK and PKC) (Bellinger et al., 1993; O'Donnell et al., 2000; Plata-Salaman and ffrench-Mullen, 1994; Schneider et al., 1998). Excitatory effects of IL- $1 \beta$ have been reported in various brain regions (for review see Schafers and Sorkin, 2008; Vezzani et al., 2011d; Viviani et al., 2007). In particular, IL- $1 \beta$ reduces synaptically-mediated GABA inhibition in area CA3 of the hippocampus via still unidentified kinases (Wang et al., 2000; Zeise et al., 1997) and increases CA1 neuron excitability by reducing NMDA channel- and voltage-gated calcium channel-induced outward current via phosphorylation of large-conductance $\mathrm{Ca}^{2+}$-dependent $\mathrm{K}^{+}$channels (Zhang et al., 2010). This cytokine also potentiates NMDA receptor function in cultured hippocampal neurons using non-transcriptional mechanisms (Lai et al., 2006; Viviani et al., 
2003), i.e. by enhancing NMDA-mediated $\mathrm{Ca}^{2+}$ influx by activating Src kinase-dependent NR2B phosphorylation (Viviani et al., 2003).

Among the TLRs, the TLR4 subtype is the most extensively studied for its involvement in brain excitability. Rat cortical application of LPS induces rapid-onset increases in neuron excitability (Rodgers et al., 2009), and these effects were prevented by IL-1ra implicating a role of released IL-1 $\beta$. At higher concentration, LPS could evoke neocortical epileptiform discharges (Rodgers et al., 2009). Notably, TLR4 can also be stimulated by "danger signals" such as High Mobility Group Box 1 (HMGB1), which are endogenous molecules released by damaged or stressed neurons and by activated astrocytes and microglia, thus generating the hypothesis that activation of TLR4 by endogenous molecules may contribute to seizure activity (see later).

Activation of the IL-1R/TLR pro-inflammatory pathway may promote neuronal hyperexcitability not only by inducing rapid and direct post-translational changes in neuronal channels and neurotransmitter receptors (Viviani et al., 2007), but also indirectly by affecting target systems involved in neuronal network hyperexcitability, e.g. inhibition of glutamate reuptake and promotion of its release by astrocytes, changes in glutamate receptor subunit expression, and by affecting BBB permeability (Friedman et al., 2009; Vezzani et al., 2011b; Wetherington et al., 2008).

\section{Blood-brain barrier and the TGF- $\beta$ signalling}

Epileptogenesis following brain insults is associated with immune response as stated above. It is noteworthy that a vascular lesion, and specifically dysfunction of the BBB is a hallmark of brain injuries, regardless of etiology (Cervos-Navarro and Lafuente, 1991; Tomkins et al., 2008). BBB dysfunction is often observed in both man and animal models of traumatic and ischemic brain injuries, within and surrounding brain tumors, in infectious and inflammatory brain diseases and in neurodegenerative diseases, including Alzheimer's and vascular dementia (Abbott et al., 2006; Neuwelt, 2004). In epilepsy, magnetic resonance imaging studies in patients with post traumatic epilepsy demonstrated permeability of BBB to contrast agents, co-localized with the presumed epileptic focus (Tomkins et al., 2011; Tomkins et al., 2008). Ultrastructural studies on human resected epileptic tissue confirm the presence of significant anatomical abnormalities at BBB components (including endothelial cells, basal membrane, and abnormal tight junctions; see Cornford, 1999). However, clinical data so far do not permit the conclusion that BBB impairment has a role in the generation or presentation of the diseases. In animal studies, a role for BBB opening was suggested in the progression of TLE based on the finding of positive immunocytochemistry to albumin following pilocarpine-induced status epilepticus and a positive correlation between the extent of BBB opening and the number of seizures (van Vliet et al., 2007). Focal opening of the BBB in the rat neocortex has been shown to result in epileptogenesis, evident by the delayed development of paroxysmal hypersynchronous activity recorded ex vivo (Ivens et al., 2007; Seiffert et al., 2004). This epileptogenic process was re-capitulated by exposure of the brain cortex to serum albumin. Extravasation of serum albumin into the cerebral cortex microenvironment following local BBB breakdown activates a TGF- $\beta$ receptor mediated signaling cascade in glia and local inflammation (Cacheaux et al., 2009). Thus, it seems plausible that damage to the microvasculature during brain insults leads to the extravasation of serum proteins and inflammation as a key step in epileptogenesis. Inflammation, on the other hand, has been shown to increase vessels permeability as well (Vezzani et al., 2011b).

TGF- $\beta$ s are pleiotropic cytokines that play a pivotal role in intercellular communication (for review see Shi and Massague, 2003), and their signaling pathways are frequently involved in cell growth, embryogenesis, differentiation, morphogenesis, wound healing, immune response, and apoptosis in a wide variety of cells (Blobe et al., 2000). TGF- $\beta$ signaling is 
mediated mainly by two serine threonine kinase receptors, TGF- $\beta$ RI and TGF- $\beta$ RII, which activate an intracellular signaling system, such as phosphorylation of the Smad protein complex and the p38 mitogen-activated protein kinase (MAPK) pathway. The canonical TGF- $\beta$ signaling activation is followed by translocation of the phosphorylated Smad2/3 complex to the nucleus regulating transcriptional responses. TGF- $\beta$ is upregulated in many epileptogenic conditions (for review see Szelenyi, 2001), including AIDS, Alzheimer's disease, stroke, tumors, or trauma. TGF- $\beta$ has also been shown to be involved in pericyteinduced BBB functions (Dohgu et al., 2005) and in microglial activation (Schilling and Eder, 2003).

The potential involvement of TGF- $\beta$ in epileptogenesis is supported by animal experiments showing TGF- $\beta$ up-regulation as part of the inflammatory response in the brains of amygdala-kindled rats (Plata-Salaman et al., 2000) and the hippocampus of rats exposed to status epilepticus (Aronica et al., 2000). Recent studies in rats demonstrated that serum albumin extravasated through a dysfunctional BBB binds to TGF- $\beta$ R and activates TGF- $\beta$ signalling (Cacheaux et al., 2009; Ivens et al., 2007). Accordingly, transcriptome analysis revealed a strikingly similar transcription modulation pattern in animals exposed to BBB dysfunction, serum-derived albumin or following direct brain exposure to physiological levels of TGF- $\beta 1$. Importantly, blocking TGF- $\beta$ signaling in the albumin model of epileptogenesis reversed inflammation and transcriptional patterns associated with activated glia and prevented the development of epileptiform activity. However, the detailed mechanisms and cellular pathways bridging TGF- $\beta$ signalling to seizures in different cell types within the neurovascular network are still a matter of investigation.

\section{COX-2 and prostanoids}

COX-2 is constitutively expressed at low to moderate levels in both neuronal cell bodies and dendritic spines in hippocampal neurons (Kaufmann et al., 1996), is regulated by synaptic activity (Kaufmann et al., 1996), and is markedly induced in neurons within an hour after a seizure (Marcheselli and Bazan, 1996), partly via a pathway involving NMDA receptors (Yamagata et al., 1993). Interestingly, each COX-2 molecule undergoes suicide inactivation after converting about 400 arachidonate molecules (Smith et al., 1996), which renders the COX-2 system very dynamic in response to changing levels of neuronal activity. COX-2 inhibition prevents LTP of the perforant path synapse onto dentate granule cells (Chen et al., 2002; Murray and O'Connor, 2003). Chen et al. (2002) further showed that the capacity for LTP can be restored by exogenous PGE2 but not PGD2 or PGF2a, and they suggested that granule cell excitability is regulated by a PGE2 pathway fueled by constitutively expressed COX-2. COX-2 expressed in postsynaptic dendritic spines regulates synaptic signaling via PGE2 (Cole-Edwards and Bazan, 2005). Somatic and dendritic membrane excitability were significantly reduced in CA1 pyramidal neurons in hippocampal slices when endogenous PGE2 was reduced by selective COX-2 inhibition. Conversely, the exogenous application of PGE2 produced significant increases in frequency of firing and excitatory postsynaptic potential amplitude, possibly by reducing potassium currents in CA1 neurons (Chen and Bazan, 2005). COX-2 inhibition decreased basal excitatory transmission in CA1 hippocampal slices, an effect prevented by cannabinoid (CB1) receptor blockade and independent of inhibitory transmission (Slanina and Schweitzer, 2005), suggesting an additional mechanism by which COX-2 may modulate hippocampal excitatory transmission. COX-2-mediated prostaglandin synthesis leads to the production of free radicals as intermediate products, which in turn can potentiate glutamate-mediated effects (Dawson et al., 1994). The production of PGE2 from TNF-alpha activated astrocytes can mediate astrocytic $\mathrm{Ca}^{2+}$-dependent glutamate release (Bezzi et al., 2001), thus contributing to ictal activity and excitotoxicity (Ding et al., 2007; Fellin et al., 2006). 


\section{Inflammation, cell loss, neuroplasticity}

Many of the mediators of neuroinflammation are not simply malicious, but carry out important physiological functions in non-pathological conditions. Neural networks in the healthy adult brain are being continuously modified by experience. This form of adaptive coping involves synaptic plasticity and neurogenesis, and low levels of pro-inflammatory cytokines, particularly IL- $1 \beta$, are important neuromodulators as first suggested by Vitkovic et al. (2000) and reviewed by Yirmaya and Goshen (2011). Neuroinflammation also modulates the degree of neurodegeneration observed in models of brain injury as described below.

\section{IL-1 $\beta$}

Genetic ablation of IL-1 $\beta$ or IL-1R1 dramatically impairs hippocampus-dependent learning and memory (Goshen et al., 2007; Spulber et al., 2009b). Conversely, overexpression of IL-1 $\beta$ disrupts memory formation (Barrientos et al., 2009; Barrientos et al., 2002), which together demonstrate a role for IL-1 $\beta$ in normal cognitive processes (Yirmiya and Goshen, 2011). The source of IL-1 $\beta$ involved in learning is microglia (Williamson et al., 2011), revealing a cogent example of glial-neuron signaling. The role played by cytokines such as IL-1 $\beta$ in neurogenesis is very complex since while they appear to support neurogenesis in physiological conditions (Yirmiya and Goshen, 2011), they can suppress this phenomenon, or contribute to aberrant positioning and function of newly generated cells in epileptic tissue (Bernardino et al., 2005; Ekdahl et al., 2009).

Aside from its normal physiological role, IL- $1 \beta$ can also mediate brain injury. IL- $1 \beta$ is induced within hours in experimental stroke models (Legos et al., 2000), and mice that have decreased IL-1 production are significantly protected from ischemic injury (Hara et al., 1997). Similarly, administering IL-1ra or IL-1 $\beta$ blocking antibodies reduces neuronal death subsequent to ischemia (Loddick and Rothwell, 1996). As described above, seizure-induced neurodegeneration can also be abrogated by preventing IL-1 synthesis; this effect is now known to be at least partly indirect because an IL-1 synthesis inhibitor greatly reduced seizure intensity (Maroso et al., 2011; Ravizza et al., 2006).

TGF- $\beta$

Although detrimental effects of TGF- $\beta$ R1 have been reported on BBB function and consequently on neuronal excitability, this pleiotropic cytokine is also endowed with neuroprotective properties (Flanders et al., 1998). Thus, a deficiency of TGF- $\beta$ signaling promotes neurodegeneration in models of Alzheimer's Disease (Tesseur et al., 2006) and lower motor neuron disease (Katsuno et al., 2010). This double-edge feature is shared by various inflammatory mediators and appears to be determined by the tissue microenvironment which follows the specific brain injury. Thus, it is well established that the outcome of inflammation is context-dependent. Microglial-derived TGF- $\beta$ appears to be required for adrenalectomy-induced neurogenesis in the hippocampus (Battista et al., 2006); likewise, TGF- $\beta$ over-expression increases neurogenesis (Mathieu et al., 2010).

COX-2

COX-2 inhibitors reduce the number of proliferating neurons in the adult hippocampus by $30-90 \%$ in seizure-naïve animals (Goncalves et al., 2010) or when administered beginning 1 day after pilocarpine-induced status epilepticus (Jung et al., 2006), thus implicating prostanoids in normal and seizure-driven neurogenesis. Because the proliferating neural progenitors do not themselves express $\mathrm{COX}-2$, neurogenesis must be influenced by nearby COX-2 expressing cells (e.g., dentate granule cells, microglia). COX-2 inhibitors also disrupt the formation of LTP and water maze acquisition under normal conditions (Cowley 
et al., 2008). In a wide variety of conditions associated with brain inflammation (e.g., TBI, local brain LPS injection, normal aging, experimental Alzheimer's Disease), COX-2 inhibitors prevented the associated memory deficits (Hein and O'Banion, 2009). Since de novo hippocampal production of neurons in the adult brain has been shown play a role in plasticity and memory (Koehl and Abrous, 2011), the effects of inflammatory mediators on neurogenesis may have an impact on their effects on LTP and cognition. The COX-2 cascade results in synthesis of five prostaglandins with potential activation of nine receptors. Of these, the EP1 receptor activated by PGE2 has been shown to mediate neurodegeneration in mice after NMDA-induced injury and cerebral ischemia (Kawano et al., 2006). The role of EP2 receptor activation is complex as described below.

\section{Pharmacological and genetic intervention on inflammation and epileptogenesis \\ IL-1/TLR signalling}

Pharmacologic or genetic interference with cytokines before a convulsant challenge provides indirect but compelling evidence of their rapid release from constitutive pools of brain resident cells. For example, blockade of IL- $1 \beta$ biosynthesis with specific ICE/ Caspase-1 inhibitors (Maroso et al., 2011; Ravizza et al., 2006), or inactivation of the biological actions of HMGB1 using receptor antagonists (Maroso et al., 2010), results in a significant delay in the onset time of kainate or bicuculline seizures. Accordingly, mice with genetic deletion of ICE/Caspase-1 or IL-1R1 gene, or with defective TLR4 signalling, showed a significant delay in the onset time of seizures (Maroso et al., 2010; Ravizza et al., 2006; Vezzani et al., 2000). The time window of these rapid effects on seizure onset $(<10$ min) is not compatible with increased de novo synthesis of IL- $1 \beta$ or HMGB1 following a convulsant challenge, therefore suggesting that these molecules are indeed released in the extracellular space from their endogenous pools in neurons and glia (Bianchi and Manfredi, 2007; Maroso et al., 2011; Ravizza et al., 2006; Spulber et al., 2009a). Increased fluxes through NMDA channels due to NR2B subunit phosphorylation appears to be a crucial mechanism underlying the proconvulsant effects of IL-1 $\beta$ and HMGB1 (Meador, 2007; Vezzani et al., 2011d). After the release of IL-1 $\beta$ and HMGB1 has occurred contributing to the occurrence of the first seizure, then de novo synthesis of both molecules is activated in microglia and astrocytes as demonstrated by immunohistochemistry, ELISA, Western blot and RT-PCR analysis in experimental models (De Simoni et al., 2000; Maroso et al., 2010; Minami et al., 1991; Ravizza et al., 2008a; Ravizza et al., 2006). Elevated brain levels of these proinflammatory molecules trigger NFkB and AP-1 mediated transcriptional changes, which in turn can perpetuate tissue inflammation via the induction of downstream inflammatory genes (Gorter et al., 2006). This second wave of inflammation and subsequent release of inflammatory molecules may contribute to seizure recurrence; indeed, the specific blockade of upstream IL-1R/TLR signalling in neurons and glia reduces the frequency of acute and chronic seizures and attenuates the concomitant level of brain inflammation (Maroso et al., 2011; Maroso et al., 2010; Ravizza et al., 2006; Ravizza et al., 2008b; Vezzani et al., 1999; Vezzani et al., 2000). In this context, experiments using systemic injections of LPS in mice and rats showed both rapid and long-term effects of inflammation on brain excitability resulting in lower seizure threshold when the animals were challenged with various convulsant drugs (Heida et al., 2004; Heida and Pittman, 2005; Heida et al., 2005; Riazi et al., 2010; Sayyah et al., 2003). LPS effects were mediated by IL-1 $\beta$ (Heida and Pittman, 2005), and by the activation of COX-2 (Sayyah et al., 2003). Long-term effects on brain excitability have been reported also when LPS is injected in rats within the first 2 post-natal weeks (Riazi et al., 2010). Thus, when rat pups treated with LPS are exposed in their adulthood to various convulsant drugs, they show a decreased seizure threshold (Galic et al., 2008; Galic et al., 2009). The same neonatal treatment primes the development of a 
more severe epilepsy and cell loss in the adult rats showing spontaneous seizures induced by pilocarpine (Auvin et al., 2010a). Exposure to LPS during the first 2 post-natal weeks also increases neuronal cell loss in response to status epilepticus in the adult (Auvin et al., 2007). These long-term effects on seizure threshold were associated with chronic hyperexcitability as electrophysiologically tested in hippocampal slices of adult rats. TLR3 stimulation in immature rats by intraventricular injection of POLY I:C was also shown to lower seizure threshold in these rats as young adults (Galic et al., 2009). Minocycline, a tetracycline antibiotic that acts by binding to bacterial ribosomes but also prevents cytokine induction in activated microglia, reverses the effects on seizure threshold both in LPS and POLY I:C models. Altered glutamate receptor subunit expression was a common feature in adult rats that were exposed to TLRs activation in their early infancy (Galic et al., 2008; Galic et al., 2009).

Since activation of TLR signalling also mimics brain responses to infection (e.g. bacterial or viral encephalities), we can envisage that this pathway may play a role in the increased risk of unprovoked seizures and development of epilepsy in the clinical setting after this type of infection (Annegers et al., 1988; Singh et al., 2008).

In summary, this set of evidence highlights the possibility that the activation of IL-1R/TLR signalling may decrease the seizure threshold, a phenomenon that also develops during epileptogenesis. Conceptually, IL-1R/TLR signaling may have an impact on epileptogenesis also via its demonstrated effects on neuronal stem cell proliferation and differentiation, by promoting cell death, and by contributing to synaptic molecular reorganization and neuronal plasticity (O'Neill and Kaltschmidt, 1997; Pitkanen and Lukasiuk, 2009; Trudler et al., 2010).

Although the major source of IL-1 $\beta$ in pathologic tissue is represented by activated glial cells, this cytokine has also been found expressed by neurons both in experimental models and in human epileptic tissue (Ravizza et al, 2008a; Ravizza et al, 2010 ) It is tempting to speculate that neuronal IL-1 $\beta$ may activate surviving programmes in neurons where it is overexpressed, via for example the transcriptional upregulation of neurotrophic factors (Rothwell and Strijbos, 1995). These neurons may then provide a persistent source of cytokine release, thus contributing to its autocrine or paracrine activities in diseased tissue.

Pharmacological intervention to block this pathway in models of epileptogenesis caused by status epilepticus is still lacking but evidence exists that inhibition of IL-1 $\beta$ signalling using ICE/Caspase-1 inhibitor or IL-1ra impairs electrical kindling development in adult (Ravizza et al., 2008b) and immature rats (Auvin et al., 2010b). Moreover, mice lacking TLR4 develop less severe epilepsy after status epilepticus than their wild-type controls (Vezzani et al., 2011c).

\section{COX-2 and prostanoids}

COX-2 is induced in selected populations of forebrain neurons within hours by traumatic brain injury or status epilepticus. Inhibition of COX-2 can either exacerbate or attenuate the neurodegeneration observed after status epilepticus depending on the strategies used to delete or inhibit COX-2 (Baik et al., 1999; Takemiya et al., 2006; Polascheck et al., 2010). The global COX-2 knock-out mouse exhibits higher mortality and larger median behavioral seizure score over a $1 \mathrm{hr}$ period after NMDA or kainate injection (Toscano et al., 2008), as do mice treated with COX-2 inhibitors before chemoconvulsant treatment (Baik et al., 1999), which complicates interpretation of the consequences of post-seizure COX-2 induction. To overcome the interpretational problems of the global COX-2 knockout, a conditional knockout mouse was recently developed in which the COX-2 gene is selectively ablated postnatally in those forebrain neurons that exhibit COX-2 induction after seizures 
(Serrano et al., 2011). In contrast to the global COX-2 knockout, the conditional COX-2 knockout mouse responded normally to pilocarpine as judged behaviorally, electrographically and by mortality rate during status epilepticus. Neuronal COX-2 ablation resulted in delayed neuroprotection of CA1 pyramidal neurons and nearby somatostatin interneurons, blunted a broad inflammatory reaction involving numerous glial-derived cytokines and other inflammatory mediators in the hippocampus, and abolished the development of a leaky BBB after seizures. A trend towards increased neurodegeneration early after status epilepticus was also found, suggesting a transient neuroprotective role for COX-2. Interestingly this neuroprotection could be mimicked by intraventricular administration of the EP2-selective agonist, butaprost, immediately after seizures. These findings suggest that seizure-induced neuronal COX-2 upregulation, presumably via the consequent synthesis and release of prostanoids, exerts a strong modulatory role in the sequelae of status epilepticus. The dual role of cyclooxygenase -combating early excitotoxicity but promoting delayed inflammatory-mediated secondary neurotoxicity- has also been reported in models of cerebral ischemia (Andreasson, 2010). Exploiting the temporal sequence of processes mediated by neuronal COX-2 will be essential to developing rational therapies targeted to COX-2 signaling pathways. The neuroprotective effects of ablating neuronal COX-2 could be replicated by delayed administration of a selective EP2 receptor antagonist (Jiang et al., 2012), consistent with the notion that activation of this proinflammatory PGE2 receptor is responsible for some COX-2 mediated consequences of status epilepticus. EP1 receptor inhibition has also been shown to be neuroprotective in the setting of focal cerebral ischemia (Kawano et al., 2006), whereas activation of EP2 receptors can be neuroprotective in models of excitotoxicity (McCullough et al., 2004; Jiang et al., 2010). EP2 receptor activation by PGE2 appears to promote both neuroprotection and inflammation that leads to secondary neurodegeneration. COX-2 activation represents one example of the detrimental or beneficial role that inflammation may play depending on the pathologic tissue context, and highlights the importance of timing for administration of EP2selective drugs.

Whether neuronal COX-2 induction mediates epileptogenesis in models of status epilepticus is not yet known. However, a careful pharmacological study of COX-2 inhibitors in a rat model of electrically-induced SE concluded that global COX-2 inhibition could not prevent the appearance of spontaneous seizures (Holtman et al., 2010). The COX-2 enzyme produces five prostanoids that act on at least nine different G-protein coupled receptors, some of which are likely to be beneficial and others detrimental based on the Vioxx experience (Fitzgerald, 2004). Rofecoxib (Vioxx) is a highly selective COX-2 inhibitor introduced by Merck in 1999 then withdrawn in 2004 when it became clear that chronic use was associated with cardiovascular toxicity. COX-2 inhibitors reduce endothelial synthesis of prostacyclin without disrupting COX-1-derived thromboxane synthesis in platelets, thus creating an imbalance that can promote platelet aggregation and consequent cardiovascular events (Grosser et al., 2010). Given the demonstrated roles described above for EP1 and EP2 receptors in neuroprotection and inflammation, it will be important to determine whether any of the prostanoid receptors is essential for epileptogenesis.

\section{Biomarkers of brain inflammation and BBB damage}

Based on the findings mentioned above, one can envisage that brain inflammation, the functions of astrocytes and microglia, endothelial cells and microvessels permeability may be considered a biomarker of tissue epileptogenicity. These pathophysiological features of brain response to injury could be exploited for therapeutic purposes, for example to identify the patient population at risk to develop epilepsy as these patients might benefit from targetspecific treatment (e.g. anti-inflammatory). A similar approach could be used to identify epileptic patients with drug-resistant diseases which might be related to BBB impairment or 
active inflammation. Finally, these biomarkers may be used to identify seizure foci with highest degree of epileptogenicity for surgical or alternative therapeutic interventions.

Imaging techniques could be advocated and developed to detect and possibly quantify inflammation in the brain of epileptic patients, or those individuals at risk to develop epilepsy. Initial studies have been developed using PET ligands to detect activated microglia in seizure foci (Banati, 2002; Butler et al., 2011; Hirvonen et al., 2010; Kumar et al., 2008); MR spectroscopy could also be a promising way to go since it allows monitoring and quantifying the degree of astrocytic activation in specific brain regions (Hammen et al., 2008; Mizuno et al., 2000; Turkdogan-Sozuer et al., 2000). Changes in T2 signals in experimental models of febrile status which may reflect oedema associated with BBB breakdown, have been described as possibly predictive of the subsequent development of epilepsy (Dubé et al., 2010). More direct methods for the detection and quantification of BBB permeability changes are being developed; while preliminary reports suggest a significant number of injury-related epileptic patients showing BBB damage (Tomkins et al., 2011; Tomkins et al., 2008), future studies are awaited to clarify to what extent vascular permeability reflects brain inflammatory response and/or per se may predict seizures. Further development of more sensitive and specific tools is mandatory, as well as methods to detect specific inflammatory molecules in brain, or to visualize brain vessels' upregulation of inflammatory mediators, or for measuring the extent of BBB breakdown.

Biochemical measurements of inflammatory mediators in blood and serum is another, not mutually exclusive approach (Aronica and Crino, 2011). The drawbacks of these types of measurements include a short half life of cytokines in serum and the difficulty to confirm that peripheral biomarkers reliably reflect their brain levels. This is due to the large variability due to the size of brain region involved, vascular permeability and the presence of significant peripheral sources for cytokines; all interfere with the interpretation of the obtained measures. CSF measurements should give a more direct measure of the inflammatory mediators released from epileptic tissue. However, these samples are not routinely available, and when obtained from lumbar pucture, dilution effects render the levels of relevant cytokines undetectable, or not readily reflecting the local inflammation. Similar to blood measures, CSF levels lack information on the spatial characteristics of the brain's inflammatory response and may vary significantly depending on the extent of the lesion.

The future challenge is therefore to characterize markers of inflammation using novel molecular imaging approaches, which will allow both quantitative and reliable measure of vessels permeability, glia functions and inflammatory response in distinct brain regions.

\section{Conclusions}

It has become clear over the past two decades that the brain is immunologically active. The brain innate immune response to injury or excessive neuronal activity is orchestrated mainly by its resident microglial and astrocytic populations, but even neurons play a key role. For example, prostaglandins produced by neuronal COX-2 regulate signaling pathways involved in synaptic plasticity under normal conditions, but in response to prolonged seizures the rapid induction of neuronal COX-2 triggers or strongly influences the ensuing neuroimmune response (Serrano et al., 2011).

Chronic neuroinflammation is an unwelcome but insistent guest in the brain undergoing epileptogenesis, being manifested by activity-dependent cytokine and chemokine release and, in models involving brain injury, frank astrogliosis and microglial activation as well as infiltration of leukocytes from the blood (Fabene et al., 2008; Zattoni et al., 2011). We have 
focused here on roles for three prominent inflammatory mediators (IL- $1 \beta$, TGF- $\beta 1$ and COX-2) in phenomena associated with the epileptogenic brain, namely neurodegeneration, neurogenesis, synaptic plasticity and regulation of BBB permeability, but their involvement in the development of epilepsy itself has so far remained elusive. Anticonvulsant effects of drugs antagonizing IL-1R/TLR signalling have been reported extensively, and evidence of anticonvulsant effects of some COX-2 inhibitors also exist in acute or chronic seizure models. However, these anti-ictal properties do not necessarily predict that antiepileptogenic effects will develop by blocking the same pathways after an precipitating epileptogenic injury. A crucial question remains whether any inflammatory mediator will become a successful anti-epileptogenic drug target.

Drugs that block specific inflammatory signals have entered clinical trials as potential therapeutics for autoimmune and inflammatory pathologies, and may also have therapeutic potential in epilepsies associated with proinflammatory processes in the brain (Vezzani et al, 2010). Targeting of novel mechanisms, such as inflammation, as an anti-epileptogenic strategy should be considered, with the intent of providing disease-modifying drugs that interfere with crucial etiopathogenetic mechanisms. This challenge should also take into careful consideration the dual role (i.e. beneficial vs detrimental) of some inflammatory mediators and the possible immunosuppressive effects which may arise from a prolonged anti-inflammatory treatment. Preventing the appearance of epilepsy in those at risk is the ultimate goal, but a disease modifying drug that regulates inflammation to reduce the frequency or intensity of epileptic seizures is highly worthwhile and now seems well within reach based on extensive animal model evidence (Friedman and Dingledine, 2011; Ravizza et al., 2011; Vezzani et al., 2011a).

\section{Acknowledgments}

Supported in part by NINDS grants 1 R21 NS074169, 1 U01 NS074509, and by the CounterAct program, Office of the Director, NIH, and NINDS grant number 2 U01 NS058158 (RD), and by Fondazione Cariplo, Fondazione Monzino and Regione Lombardia under Institutional Agreement n. 14501A (to AV).

\section{List of references}

Abbott NJ, Ronnback L, Hansson E. Astrocyte-endothelial interactions at the blood-brain barrier. Nat Rev Neurosci. 2006; 7:41-53. [PubMed: 16371949]

Akassoglou K, Probert L, Kontogeorgos G, Kollias G. Astrocyte-specific but not neuron-specific transmembrane TNF triggers inflammation and degeneration in the central nervous system of transgenic mice. J Immunol. 1997; 158:438-445. [PubMed: 8977220]

Allan SM, Tyrrell PJ, Rothwell NJ. Interleukin-1 and neuronal injury. Nat Rev Immunol. 2005; 5:629640. [PubMed: 16034365]

Andreasson K. Prostaglandin signalling in cerebral ischaemia. Br J Pharmacol. 2010; 160:844-846. [PubMed: 20590583]

Annegers JF, Hauser WA, Beghi E, Nicolosi A, Kurland LT. The risk of unprovoked seizures after encephalitis and meningitis. Neurology. 1988; 38:1407-1410. [PubMed: 3412588]

Aronica E, Boer K, van Vliet EA, Redeker S, Baayen JC, Spliet WG, van Rijen PC, Troost D, da Silva FH, Wadman WJ, Gorter JA. Complement activation in experimental and human temporal lobe epilepsy. Neurobiol Dis. 2007; 26:497-511. [PubMed: 17412602]

Aronica E, Crino PB. Inflammation in epilepsy: clinical observations. Epilepsia. 2011; 52(3):26-32. [PubMed: 21542843]

Aronica E, van Vliet EA, Mayboroda OA, Troost D, da Silva FH, Gorter JA. Upregulation of metabotropic glutamate receptor subtype mGluR3 and mGluR5 in reactive astrocytes in a rat model of mesial temporal lobe epilepsy. Eur J Neurosci. 2000; 12:2333-2344. [PubMed: 10947812]

Auvin S, Mazarati A, Shin D. Inflammation enhances epileptogenesis in immature rat brain. Neurobiol Dis. 2010a; 40:303-310. [PubMed: 20600912] 
Auvin S, Shin D, Mazarati A, Nakagawa J, Miyamoto J, Sankar R. Inflammation exacerbates seizureinduced injury in the immature brain. Epilepsia. 2007; 48(5):27-34. [PubMed: 17910578]

Auvin S, Shin D, Mazarati A, Sankar R. Inflammation induced by LPS enhances epileptogenesis in immature rat and may be partially reversed by IL1RA. Epilepsia. 2010b; 51(3):34-38. [PubMed: 20618397]

Baik EJ, Kim EJ, Lee SH, Moon C. Cyclooxygenase-2 selective inhibitors aggravate kainic acid induced seizure and neuronal cell death in the hippocampus. Brain Res. 1999; 843:118-129. [PubMed: 10528118]

Ban E, Milon G, Prudhomme N, Fillion G, Haour F. Receptors for interleukin-1 (alpha and beta) in mouse brain: mapping and neuronal localization in hippocampus. Neuroscience. 1991; 43:21-30. [PubMed: 1833666]

Banati RB. Visualising microglial activation in vivo. Glia. 2002; 40:206-217. [PubMed: 12379908]

Barrientos RM, Frank MG, Hein AM, Higgins EA, Watkins LR, Rudy JW, Maier SF. Time course of hippocampal IL-1 beta and memory consolidation impairments in aging rats following peripheral infection. Brain Behav Immun. 2009; 23:46-54. [PubMed: 18664380]

Barrientos RM, Higgins EA, Sprunger DB, Watkins LR, Rudy JW, Maier SF. Memory for context is impaired by a post context exposure injection of interleukin-1 beta into dorsal hippocampus. Behav Brain Res. 2002; 134:291-298. [PubMed: 12191816]

Battista D, Ferrari CC, Gage FH, Pitossi FJ. Neurogenic niche modulation by activated microglia: transforming growth factor beta increases neurogenesis in the adult dentate gyrus. Eur J Neurosci. 2006; 23:83-93. [PubMed: 16420418]

Bellinger FP, Madamba S, Siggins GR. Interleukin 1 beta inhibits synaptic strength and long-term potentiation in the rat CA1 hippocampus. Brain Res. 1993; 628:227-234. [PubMed: 8313151]

Bernardino L, Ferreira R, Cristovao AJ, Sales F, Malva JO. Inflammation and neurogenesis in temporal lobe epilepsy. Curr Drug Targets CNS Neurol Disord. 2005; 4:349-360. [PubMed: 16101554]

Bezzi P, Domercq M, Brambilla L, Galli R, Schols D, De Clercq E, Vescovi A, Bagetta G, Kollias G, Meldolesi J, Volterra A. CXCR4-activated astrocyte glutamate release via TNFalpha: amplification by microglia triggers neurotoxicity. Nat Neurosci. 2001; 4:702-710. [PubMed: 11426226]

Bianchi ME, Manfredi AA. High-mobility group box 1 (HMGB1) protein at the crossroads between innate and adaptive immunity. Immunol Rev. 2007; 220:35-46. [PubMed: 17979838]

Blobe GC, Schiemann WP, Lodish HF. Role of transforming growth factor beta in human disease. N Engl J Med. 2000; 342:1350-1358. [PubMed: 10793168]

Butler T, Ichise M, Teich AF, Gerard E, Osborne J, French J, Devinsky O, Kuzniecky R, Gilliam F, Pervez F, Provenzano F, Goldsmith S, Vallabhajosula S, Stern E, Silbersweig D. Imaging Inflammation in a Patient with Epilepsy Due to Focal Cortical Dysplasia. J Neuroimaging. 201110.1111/j.1552-6569.2010.00572.x

Cacheaux LP, Ivens S, David Y, Lakhter AJ, Bar-Klein G, Shapira M, Heinemann U, Friedman A, Kaufer D. Transcriptome profiling reveals TGF-beta signaling involvement in epileptogenesis. J Neurosci. 2009; 29:8927-8935. [PubMed: 19605630]

Campbell IL, Abraham CR, Masliah E, Kemper P, Inglis JD, Oldstone MB, Mucke L. Neurologic disease induced in transgenic mice by cerebral overexpression of interleukin 6. Proc Natl Acad Sci U S A. 1993; 90:10061-10065. [PubMed: 7694279]

Cervos-Navarro J, Lafuente JV. Traumatic brain injuries: structural changes. J Neurol Sci. 1991; 103(Suppl):S3-14. [PubMed: 1940963]

Chakravarty S, Herkenham M. Toll-like receptor 4 on nonhematopoietic cells sustains CNS inflammation during endotoxemia, independent of systemic cytokines. J Neurosci. 2005; 25:17881796. [PubMed: 15716415]

Chen C, Bazan NG. Lipid signaling: sleep, synaptic plasticity, and neuroprotection. Prostaglandins Other Lipid Mediat. 2005; 77:65-76. [PubMed: 16099392]

Chen C, Magee JC, Bazan NG. Cyclooxygenase-2 regulates prostaglandin E2 signaling in hippocampal long-term synaptic plasticity. J Neurophysiol. 2002; 87:2851-2857. [PubMed: 12037188] 
Cole-Edwards KK, Bazan NG. Lipid signaling in experimental epilepsy. Neurochem Res. 2005; 30:847-853. [PubMed: 16187219]

Cornford EM. Epilepsy and the blood brain barrier: endothelial cell responses to seizures. Adv Neurol. 1999; 79:845-862. [PubMed: 10514868]

Cowley TR, Fahey B, O'Mara SM. COX-2, but not COX-1, activity is necessary for the induction of perforant path long-term potentiation and spatial learning in vivo. Eur J Neurosci. 2008; 27:29993008. [PubMed: 18540883]

Croll SD, Goodman JH, Scharfman HE. Vascular endothelial growth factor (VEGF) in seizures: a double-edged sword. Adv Exp Med Biol. 2004; 548:57-68. [PubMed: 15250585]

Dawson VL, Brahmbhatt HP, Mong JA, Dawson TM. Expression of inducible nitric oxide synthase causes delayed neurotoxicity in primary mixed neuronal-glial cortical cultures. Neuropharmacology. 1994; 33:1425-1430. [PubMed: 7532825]

De Simoni MG, Perego C, Ravizza T, Moneta D, Conti M, Marchesi F, De Luigi A, Garattini S, Vezzani A. Inflammatory cytokines and related genes are induced in the rat hippocampus by limbic status epilepticus. Eur J Neurosci. 2000; 12:2623-2633. [PubMed: 10947836]

Ding S, Fellin T, Zhu Y, Lee SY, Auberson YP, Meaney DF, Coulter DA, Carmignoto G, Haydon PG. Enhanced astrocytic $\mathrm{Ca} 2+$ signals contribute to neuronal excitotoxicity after status epilepticus. J Neurosci. 2007; 27:10674-10684. [PubMed: 17913901]

Dohgu S, Takata F, Yamauchi A, Nakagawa S, Egawa T, Naito M, Tsuruo T, Sawada Y, Niwa M, Kataoka Y. Brain pericytes contribute to the induction and up-regulation of blood-brain barrier functions through transforming growth factor-beta production. Brain Res. 2005; 1038:208-215. [PubMed: 15757636]

Dubé C, Vezzani A, Behrens M, Bartfai T, Baram TZ. Interleukin-1beta contributes to the generation of experimental febrile seizures. Ann Neurol. 2005; 57:152-155. [PubMed: 15622539]

Dubé CM, Ravizza T, Hamamura M, Zha Q, Keebaugh A, Fok K, Andres AL, Nalcioglu O, Obenaus A, Vezzani A, Baram TZ. Epileptogenesis provoked by prolonged experimental febrile seizures: mechanisms and biomarkers. J Neurosci. 2010; 30:7484-7494. [PubMed: 20519523]

Ekdahl CT, Kokaia Z, Lindvall O. Brain inflammation and adult neurogenesis: the dual role of microglia. Neuroscience. 2009; 158:1021-1029. [PubMed: 18662748]

Ericsson A, Liu C, Hart RP, Sawchenko PE. Type 1 interleukin-1 receptor in the rat brain: distribution, regulation, and relationship to sites of IL-1-induced cellular activation. J Comp Neurol. 1995; 361:681-698. [PubMed: 8576422]

Fabene PF, Mora GN, Martinello M, Rossi B, Merigo F, Ottoboni L, Bach S, Angiari S, Benati D, Chakir A, Zanetti L, Schio F, Osculati A, Marzola P, Nicolato E, Homeister JW, Xia L, Lowe JB, McEver RP, Osculati F, Sbarbati A, Butcher EC, Constantin G. A role for leukocyte-endothelial adhesion mechanisms in epilepsy. Nat Med. 2008; 14:1377-1383. [PubMed: 19029985]

Fellin T, Gomez-Gonzalo M, Gobbo S, Carmignoto G, Haydon PG. Astrocytic glutamate is not necessary for the generation of epileptiform neuronal activity in hippocampal slices. J Neurosci. 2006; 26:9312-9322. [PubMed: 16957087]

Fitzgerald GA. Coxibs and cardiovascular disease. N Engl J Med. 2004; 351:1709-1711. [PubMed: 15470192]

Flanders KC, Ren RF, Lippa CF. Transforming growth factor-betas in neurodegenerative disease. Prog Neurobiol. 1998; 54:71-85. [PubMed: 9460794]

Friedman A, Dingledine R. Molecular cascades that mediate the influence of inflammation on epilepsy. Epilepsia. 2011; 52(3):33-39. [PubMed: 21542844]

Friedman A, Kaufer D, Heinemann U. Blood-brain barrier breakdown-inducing astrocytic transformation: novel targets for the prevention of epilepsy. Epilepsy Res. 2009; 85:142-149. [PubMed: 19362806]

Galic MA, Riazi K, Heida JG, Mouihate A, Fournier NM, Spencer SJ, Kalynchuk LE, Teskey GC, Pittman QJ. Postnatal inflammation increases seizure susceptibility in adult rats. J Neurosci. 2008; 28:6904-6913. [PubMed: 18596165]

Galic MA, Riazi K, Henderson AK, Tsutsui S, Pittman QJ. Viral-like brain inflammation during development causes increased seizure susceptibility in adult rats. Neurobiol Dis. 2009; 36:343351. [PubMed: 19660546] 
Goncalves MB, Williams EJ, Yip P, Yanez-Munoz RJ, Williams G, Doherty P. The COX-2 inhibitors, meloxicam and nimesulide, suppress neurogenesis in the adult mouse brain. Br J Pharmacol. 2010; 159:1118-1125. [PubMed: 20136845]

Gorter JA, van Vliet EA, Aronica E, Breit T, Rauwerda H, Lopes da Silva FH, Wadman WJ. Potential new antiepileptogenic targets indicated by microarray analysis in a rat model for temporal lobe epilepsy. J Neurosci. 2006; 26:11083-11110. [PubMed: 17065450]

Goshen I, Kreisel T, Ounallah-Saad H, Renbaum P, Zalzstein Y, Ben-Hur T, Levy-Lahad E, Yirmiya R. A dual role for interleukin-1 in hippocampal-dependent memory processes. Psychoneuroendocrinology. 2007; 32:1106-1115. [PubMed: 17976923]

Grosser T, Yu Y, Fitzgerald GA. Emotion recollected in tranquility: lessons learned from the COX-2 saga. Annu Rev Med. 2010; 61:17-33. [PubMed: 20059330]

Hammen T, Hildebrandt M, Stadlbauer A, Doelken M, Engelhorn T, Kerling F, Kasper B, Romstoeck J, Ganslandt O, Nimsky C, Blumcke I, Doerfler A, Stefan H. Non-invasive detection of hippocampal sclerosis: correlation between metabolite alterations detected by (1)H-MRS and neuropathology. NMR Biomed. 2008; 21:545-552. [PubMed: 18035849]

Hara H, Friedlander RM, Gagliardini V, Ayata C, Fink K, Huang Z, Shimizu-Sasamata M, Yuan J, Moskowitz MA. Inhibition of interleukin 1beta converting enzyme family proteases reduces ischemic and excitotoxic neuronal damage. Proc Natl Acad Sci U S A. 1997; 94:2007-2012. [PubMed: 9050895]

Heida JG, Boisse L, Pittman QJ. Lipopolysaccharide-induced febrile convulsions in the rat: short-term sequelae. Epilepsia. 2004; 45:1317-1329. [PubMed: 15509232]

Heida JG, Pittman QJ. Causal links between brain cytokines and experimental febrile convulsions in the rat. Epilepsia. 2005; 46:1906-1913. [PubMed: 16393156]

Heida JG, Teskey GC, Pittman QJ. Febrile convulsions induced by the combination of lipopolysaccharide and low-dose kainic acid enhance seizure susceptibility, not epileptogenesis, in rats. Epilepsia. 2005; 46:1898-1905. [PubMed: 16393155]

Hein AM, O'Banion MK. Neuroinflammation and memory: the role of prostaglandins. Mol Neurobiol. 2009; 40:15-32. [PubMed: 19365736]

Hirvonen, J.; Kreisl, W.; Fujita, M.; Dustin, I.; Miranda, S.; Zhang, Y.; Morse, C.; Pike, VR.; Innis, R.; Theodore, WH. Increased in vivo expression of an inflammatory marker in temporal lobe epilepsy. American Epilepsy Society; S. Antonio (TX): 2010. Abst 3.230

Holtman L, van Vliet EA, Edelbroek PM, Aronica E, Gorter JA. Cox-2 inhibition can lead to adverse effects in a rat model for temporal lobe epilepsy. Epilepsy Res. 2010; 91:49-56. [PubMed: 20643531]

Ivens S, Kaufer D, Flores LP, Bechmann I, Zumsteg D, Tomkins O, Seiffert E, Heinemann U, Friedman A. TGF-beta receptor-mediated albumin uptake into astrocytes is involved in neocortical epileptogenesis. Brain. 2007; 130:535-547. [PubMed: 17121744]

Jiang J, Ganesh T, DU Y, Thepchatri P, Rojas A, Lewis I, Kurtkaya S, Li L, Qui M, Serrano G, Shaw R, Sun A, Dingledine R. Neuroprotection by selective allosteric potentiators of the EP2 prostaglandin receptor. Proc Nat Acad Sci USA. 2010; 107:2307-2312. [PubMed: 20080612]

Jiang K, Ganesh T, Du Y, Quan Y, Serrano G, Qui M, Speigel I, Rojas A, Lelutiu N, Dingledine R. Small molecule antagonist reveals seizure-induced mediation of neuronal injury by prostaglandin E2 receptor subtype EP2. Proc Nat Acad Sci USA. 2012 in press.

Jung KH, Chu K, Lee ST, Kim J, Sinn DI, Kim JM, Park DK, Lee JJ, Kim SU, Kim M, Lee SK, Roh JK. Cyclooxygenase-2 inhibitor, celecoxib, inhibits the altered hippocampal neurogenesis with attenuation of spontaneous recurrent seizures following pilocarpine-induced status epilepticus. Neurobiol Dis. 2006; 23:237-246. [PubMed: 16806953]

Katsuno M, Adachi H, Minamiyama M, Waza M, Doi H, Kondo N, Mizoguchi H, Nitta A, Yamada K, Banno H, Suzuki K, Tanaka F, Sobue G. Disrupted transforming growth factor-beta signaling in spinal and bulbar muscular atrophy. J Neurosci. 2010; 30:5702-5712. [PubMed: 20410122]

Kaufmann WE, Worley PF, Pegg J, Bremer M, Isakson P. COX-2, a synaptically induced enzyme, is expressed by excitatory neurons at postsynaptic sites in rat cerebral cortex. Proc Natl Acad Sci U S A. 1996; 93:2317-2321. [PubMed: 8637870] 
Kawano T, Anrather J, Zhou P, Park L, Wang G, Frys KA, Kunz A, Cho S, Orio M, Iadecola C. Prostaglandin E2 EP1 receptors: downstream effectors of COX-2 neurotoxicity. Nat Med. 2006; 12:225-229. [PubMed: 16432513]

Koehl M, Abrous DN. A new chapter in the field of memory: adult hippocampal neurogenesis. Eur J Neurosci. 2011; 33:1101-1114. [PubMed: 21395854]

Kulkarni SK, Dhir A. Cyclooxygenase in epilepsy: from perception to application. Drugs Today (Barc). 2009; 45:135-154. [PubMed: 19343233]

Kumar A, Chugani HT, Luat A, Asano E, Sood S. Epilepsy surgery in a case of encephalitis: use of 11C-PK11195 positron emission tomography. Pediatr Neurol. 2008; 38:439-442. [PubMed: 18486829]

Lai AY, Swayze RD, El-Husseini A, Song C. Interleukin-1 beta modulates AMPA receptor expression and phosphorylation in hippocampal neurons. J Neuroimmunol. 2006; 175:97-106. [PubMed: 16626814]

Legos JJ, Whitmore RG, Erhardt JA, Parsons AA, Tuma RF, Barone FC. Quantitative changes in interleukin proteins following focal stroke in the rat. Neurosci Lett. 2000; 282:189-192. [PubMed: 10717423]

Loddick SA, Rothwell NJ. Neuroprotective effects of human recombinant interleukin-1 receptor antagonist in focal cerebral ischaemia in the rat. J Cereb Blood Flow Metab. 1996; 16:932-940. [PubMed: 8784237]

Marcheselli VL, Bazan NG. Sustained induction of prostaglandin endoperoxide synthase-2 by seizures in hippocampus. Inhibition by a platelet-activating factor antagonist. J Biol Chem. 1996; 271:24794-24799. [PubMed: 8798751]

Maroso M, Balosso S, Ravizza T, Iori V, Wright CI, French J, Vezzani A. Interleukin-1beta biosynthesis inhibition reduces acute seizures and drug resistant chronic epileptic activity in mice. Neurotherapeutics. 2011; 8:304-315. [PubMed: 21431948]

Maroso M, Balosso S, Ravizza T, Liu J, Aronica E, Iyer AM, Rossetti C, Molteni M, Casalgrandi M, Manfredi AA, Bianchi ME, Vezzani A. Toll-like receptor 4 and high-mobility group box-1 are involved in ictogenesis and can be targeted to reduce seizures. Nat Med. 2010; 16:413-419. [PubMed: 20348922]

Mathieu P, Piantanida AP, Pitossi F. Chronic expression of transforming growth factor-beta enhances adult neurogenesis. Neuroimmunomodulation. 2010; 17:200-201. [PubMed: 20134202]

McCullough L, Wu L, Haughey N, Liang X, Hand T, Wang Q, Breyer RM, Andreasson K. Neuroprotective function of the PGE2 EP2 receptor in cerebral ischemia. J Neurosci. 2004; 24:257-268. [PubMed: 14715958]

Meador KJ. The basic science of memory as it applies to epilepsy. Epilepsia. 2007; 48(9):23-25. [PubMed: 18047596]

Minami M, Kuraishi Y, Satoh M. Effects of kainic acid on messenger RNA levels of IL-1 beta, IL-6, TNF alpha and LIF in the rat brain. Biochem Biophys Res Commun. 1991; 176:593-598. [PubMed: 1709015]

Mizuno S, Takahashi Y, Kato Z, Goto H, Kondo N, Hoshi H. Magnetic resonance spectroscopy of tubers in patients with tuberous sclerosis. Acta Neurol Scand. 2000; 102:175-178. [PubMed: 10987377]

Murray HJ, O'Connor JJ. A role for COX-2 and p38 mitogen activated protein kinase in long-term depression in the rat dentate gyrus in vitro. Neuropharmacology. 2003; 44:374-380. [PubMed: 12604095]

Neuwelt EA. Mechanisms of disease: the blood-brain barrier. Neurosurgery. 2004; 54:131-140. discussion 141-132. [PubMed: 14683550]

O'Donnell E, Vereker E, Lynch MA. Age-related impairment in LTP is accompanied by enhanced activity of stress-activated protein kinases: analysis of underlying mechanisms. Eur J Neurosci. 2000; 12:345-352. [PubMed: 10651889]

O'Neill LA, Kaltschmidt C. NF-kappa B: a crucial transcription factor for glial and neuronal cell function. Trends Neurosci. 1997; 20:252-258. [PubMed: 9185306] 
Oprica M, Eriksson C, Schultzberg M. Inflammatory mechanisms associated with brain damage induced by kainic acid with special reference to the interleukin-1 system. J Cell Mol Med. 2003; 7:127-140. [PubMed: 12927051]

Peltier DC, Simms A, Farmer JR, Miller DJ. Human neuronal cells possess functional cytoplasmic and TLR-mediated innate immune pathways influenced by phosphatidylinositol-3 kinase signaling. J Immunol. 2010; 184:7010-7021. [PubMed: 20483728]

Pitkanen A, Lukasiuk K. Molecular and cellular basis of epileptogenesis in symptomatic epilepsy. Epilepsy Behav. 2009; 14(1):16-25. [PubMed: 18835369]

Plata-Salaman CR, ffrench-Mullen JM. Interleukin-1 beta inhibits Ca2+ channel currents in hippocampal neurons through protein kinase C. Eur J Pharmacol. 1994; 266:1-10. [PubMed: 8137877]

Plata-Salaman CR, Ilyin SE, Turrin NP, Gayle D, Flynn MC, Romanovitch AE, Kelly ME, Bureau Y, Anisman H, McIntyre DC. Kindling modulates the IL-1beta system, TNF-alpha, TGF-beta1, and neuropeptide mRNAs in specific brain regions. Brain Res Mol Brain Res. 2000; 75:248-258. [PubMed: 10686345]

Polascheck N, Banksthal M, Löscher W. The COX-2 inhibitor parecoxib is neuroprotective but not antiepileptogenic in the pilocarpine model of temporal lobe epilepsy. 2010; 224:219-233.

Ravizza, T.; Balosso, S.; Aronica, E.; Vezzani, A. Brain Inflammation and epilepsy. In: Rho, JM.; Sankar, R.; Strafstrom, CE., editors. Epilepsy Mechanisms, models, and translational perpsectives. CRC Press; Boca Raton, FL: 2010. p. 45-59.

Ravizza T, Balosso S, Vezzani A. Inflammation and prevention of epileptogenesis. Neurosci Lett. 2011; 497:223-230. [PubMed: 21362451]

Ravizza T, Gagliardi B, Noé F, Boer K, Aronica E, Vezzani A. Innate and adaptive immunity during epileptogenesis and spontaneous seizures: evidence from experimental models and human temporal lobe epilepsy. Neurobiol Dis. 2008a; 29:142-160. [PubMed: 17931873]

Ravizza T, Lucas SM, Balosso S, Bernardino L, Ku G, Noé F, Malva J, Randle JC, Allan S, Vezzani A. Inactivation of caspase-1 in rodent brain: a novel anticonvulsive strategy. Epilepsia. 2006; 47:1160-1168. [PubMed: 16886979]

Ravizza T, Noé F, Zardoni D, Vaghi V, Sifringer M, Vezzani A. Interleukin Converting Enzyme inhibition impairs kindling epileptogenesis in rats by blocking astrocytic IL-1beta production. Neurobiol Dis. 2008b; 31:327-333. [PubMed: 18632279]

Ravizza T, Vezzani A. Status epilepticus induces time-dependent neuronal and astrocytic expression of interleukin-1 receptor type I in the rat limbic system. Neuroscience. 2006; 137:301-308. [PubMed: 16289587]

Riazi K, Galic MA, Pittman QJ. Contributions of peripheral inflammation to seizure susceptibility: cytokines and brain excitability. Epilepsy Res. 2010; 89:34-42. [PubMed: 19804959]

Rodgers KM, Hutchinson MR, Northcutt A, Maier SF, Watkins LR, Barth DS. The cortical innate immune response increases local neuronal excitability leading to seizures. Brain. 2009; 132:2478-2486. [PubMed: 19567702]

Rothwell NJ, Strijbos PJ. Cytokines in neurodegeneration and repair. Int J Dev Neurosci. 1995:13179_ 185.

Sayyah M, Javad-Pour M, Ghazi-Khansari M. The bacterial endotoxin lipopolysaccharide enhances seizure susceptibility in mice: involvement of proinflammatory factors: nitric oxide and prostaglandins. Neuroscience. 2003; 122:1073-1080. [PubMed: 14643773]

Schafers M, Sorkin L. Effect of cytokines on neuronal excitability. Neurosci Lett. 2008; 437:188-193. [PubMed: 18420346]

Schilling T, Eder C. Effects of kinase inhibitors on TGF-beta induced upregulation of Kv1.3 K+ channels in brain macrophages. Pflugers Arch. 2003; 447:312-315. [PubMed: 12961089]

Schneider H, Pitossi F, Balschun D, Wagner A, del Rey A, Besedovsky HO. A neuromodulatory role of interleukin-1beta in the hippocampus. Proc Natl Acad Sci U S A. 1998; 95:7778-7783. [PubMed: 9636227]

Seiffert E, Dreier JP, Ivens S, Bechmann I, Tomkins O, Heinemann U, Friedman A. Lasting bloodbrain barrier disruption induces epileptic focus in the rat somatosensory cortex. J Neurosci. 2004; 24:7829-7836. [PubMed: 15356194] 
Serrano GE, Lelutiu N, Rojas A, Cochi S, Shaw R, Makinson CD, Wang D, FitzGerald GA, Dingledine R. Ablation of cyclooxygenase-2 in forebrain neurons is neuroprotective and dampens brain inflammation after status epilepticus. J Neurosci. 2011; 31:14850-14860. [PubMed: 22016518]

Shi Y, Massague J. Mechanisms of TGF-beta signaling from cell membrane to the nucleus. Cell. 2003; 113:685-700. [PubMed: 12809600]

Singh G, Prabhakar S, Modi M. Central nervous system infections and epilepsy. Epilepsia. 2008; 49(6):1. [PubMed: 18754953]

Slanina KA, Schweitzer P. Inhibition of cyclooxygenase-2 elicits a CB1-mediated decrease of excitatory transmission in rat CA1 hippocampus. Neuropharmacology. 2005; 49:653-659. [PubMed: 15936781]

Smith WL, Garavito RM, DeWitt DL. Prostaglandin endoperoxide H synthases (cyclooxygenases)-1 and -2. J Biol Chem. 1996; 271:33157-33160. [PubMed: 8969167]

Spulber S, Bartfai T, Schultzberg M. IL-1/IL-1ra balance in the brain revisited - evidence from transgenic mouse models. Brain Behav Immun. 2009a; 23:573-579. [PubMed: 19258032]

Spulber S, Mateos L, Oprica M, Cedazo-Minguez A, Bartfai T, Winblad B, Schultzberg M. Impaired long term memory consolidation in transgenic mice overexpressing the human soluble form of IL-1ra in the brain. J Neuroimmunol. 2009b; 208:46-53. [PubMed: 19211154]

Stalder AK, Carson MJ, Pagenstecher A, Asensio VC, Kincaid C, Benedict M, Powell HC, Masliah E, Campbell IL. Late-onset chronic inflammatory encephalopathy in immune-competent and severe combined immune-deficient (SCID) mice with astrocyte-targeted expression of tumor necrosis factor. Am J Pathol. 1998; 153:767-783. [PubMed: 9736027]

Szelenyi J. Cytokines and the central nervous system. Brain Res Bull. 2001; 54:329-338. [PubMed: 11306183]

Takao T, Tracey DE, Mitchell WM, De Souza EB. Interleukin-1 receptors in mouse brain: characterization and neuronal localization. Endocrinology. 1990; 127:3070-3078. [PubMed: 2147409]

Takemiya T, Maehara M, Matsumura K, Yasuda S, Sugiura H, Yamagata K. Prostaglandin E2 produced by late induced COX-2 stimulates hippocampal neuron loss after seizure in the CA3 region. Neurosci Res. 2006; 56:103-110. [PubMed: 16837093]

Tesseur I, Zou K, Esposito L, Bard F, Berber E, Can JV, Lin AH, Crews L, Tremblay P, Mathews P, Mucke L, Masliah E, Wyss-Coray T. Deficiency in neuronal TGF-beta signaling promotes neurodegeneration and Alzheimer's pathology. J Clin Invest. 2006; 116:3060-3069. [PubMed: 17080199]

Tomkins O, Feintuch A, Benifla M, Cohen A, Friedman A, Shelef I. Blood-brain barrier breakdown following traumatic brain injury: a possible role in posttraumatic epilepsy. Cardiovasc Psychiatry Neurol. 2011; 2011:765923. [PubMed: 21436875]

Tomkins O, Shelef I, Kaizerman I, Eliushin A, Afawi Z, Misk A, Gidon M, Cohen A, Zumsteg D, Friedman A. Blood-brain barrier disruption in post-traumatic epilepsy. J Neurol Neurosurg Psychiatry. 2008; 79:774-777. [PubMed: 17991703]

Toscano CD, Kingsley PJ, Marnett LJ, Bosetti F. NMDA-induced seizure intensity is enhanced in COX-2 deficient mice. Neurotoxicology. 2008; 29:1114-1120. [PubMed: 18834901]

Trudler D, Farfara D, Frenkel D. Toll-like receptors expression and signaling in glia cells in neuroamyloidogenic diseases: towards future therapeutic application. Mediators Inflamm. 2010; 2010

Turkdogan-Sozuer D, Ozek MM, Sav A, Dincer A, Pamir MN. Serial MRI and MRS studies with unusual findings in Rasmussen's encephalitis. Eur Radiol. 2000; 10:962-966. [PubMed: 10879711]

Turrin NP, Rivest S. Innate immune reaction in response to seizures: implications for the neuropathology associated with epilepsy. Neurobiol Dis. 2004; 16:321-334. [PubMed: 15193289]

van Vliet EA, da Costa Araujo S, Redeker S, van Schaik R, Aronica E, Gorter JA. Blood-brain barrier leakage may lead to progression of temporal lobe epilepsy. Brain. 2007; 130:521-534. [PubMed: 17124188] 
Vezzani A, Aronica E, Mazarati A, Pittman QJ. Epilepsy and brain inflammation. Exp Neurol. 2011a in press.

Vezzani A, Conti M, De Luigi A, Ravizza T, Moneta D, Marchesi F, De Simoni MG. Interleukin-1beta immunoreactivity and microglia are enhanced in the rat hippocampus by focal kainate application: functional evidence for enhancement of electrographic seizures. J Neurosci. 1999; 19:5054-5065. [PubMed: 10366638]

Vezzani A, French J, Bartfai T, Baram TZ. The role of inflammation in epilepsy. Nat Rev Neurol. 2011b; 7:31-40. [PubMed: 21135885]

Vezzani, A.; Iori, V.; Ravizza, T.; Bianchi, ME.; Maroso, M. Activation of Toll-like receptor 4 (TLR4) and Receptor for Advanced Glycation End Products (RAGE) signaling contributes to ictogenesis and epileptogenesis. Society for Neuroscience; Meeting, Washington DC Poster number 889.20: 2011c.

Vezzani A, Maroso M, Balosso S, Sanchez MA, Bartfai T. IL-1 receptor/Toll-like receptor signaling in infection, inflammation, stress and neurodegeneration couples hyperexcitability and seizures. Brain Behav Immun. 2011d; 25:1281-1289. [PubMed: 21473909]

Vezzani A, Moneta D, Conti M, Richichi C, Ravizza T, De Luigi A, De Simoni MG, Sperk G, AndellJonsson S, Lundkvist J, Iverfeldt K, Bartfai T. Powerful anticonvulsant action of IL-1 receptor antagonist on intracerebral injection and astrocytic overexpression in mice. Proc Natl Acad Sci U S A. 2000; 97:11534-11539. [PubMed: 11016948]

Vezzani A, Balosso S, Maroso M, Zardoni D, Noé F, Ravizza T. ICE/caspase 1 inhibitors and IL-1beta receptor antagonists as potential therapeutics in epilepsy. Curr Opin Investig Drugs. 2010; 11:4350.

Vezzani A, Balosso S, Maroso M, Zardoni D, Noé F, Ravizza T. ICE/caspase 1 inhibitors and IL-1beta receptor antagonists as potential therapeutics in epilepsy. Curr Opin Investig Drugs. 2010; 11:4350 .

Vitkovic L, Bockaert J, Jacque C. "Inflammatory" cytokines: neuromodulators in normal brain? J Neurochem. 2000; 74:457-471. [PubMed: 10646496]

Viviani B, Bartesaghi S, Gardoni F, Vezzani A, Behrens MM, Bartfai T, Binaglia M, Corsini E, Di Luca M, Galli CL, Marinovich M. Interleukin-1beta enhances NMDA receptor-mediated intracellular calcium increase through activation of the Src family of kinases. J Neurosci. 2003; 23:8692-8700. [PubMed: 14507968]

Viviani B, Gardoni F, Marinovich M. Cytokines and neuronal ion channels in health and disease. Int Rev Neurobiol. 2007; 82:247-263. [PubMed: 17678965]

Wang S, Cheng Q, Malik S, Yang J. Interleukin-1beta inhibits gamma-aminobutyric acid type A (GABA(A)) receptor current in cultured hippocampal neurons. J Pharmacol Exp Ther. 2000; 292:497-504. [PubMed: 10640285]

Wetherington J, Serrano G, Dingledine R. Astrocytes in the epileptic brain. Neuron. 2008; 58:168178. [PubMed: 18439402]

Williamson LL, Sholar PW, Mistry RS, Smith SH, Bilbo SD. Microglia and memory: modulation by early-life infection. J Neurosci. 2011; 31:15511-15521. [PubMed: 22031897]

Yamagata K, Andreasson KI, Kaufmann WE, Barnes CA, Worley PF. Expression of a mitogeninducible cyclooxygenase in brain neurons: regulation by synaptic activity and glucocorticoids. Neuron. 1993; 11:371-386. [PubMed: 8352945]

Yirmiya R, Goshen I. Immune modulation of learning, memory, neural plasticity and neurogenesis. Brain Behav Immun. 2011; 25:181-213. [PubMed: 20970492]

Zattoni M, Mura ML, Deprez F, Schwendener RA, Engelhardt B, Frei K, Fritschy JM. Brain infiltration of leukocytes contributes to the pathophysiology of temporal lobe epilepsy. $\mathrm{J}$ Neurosci. 2011; 31:4037-4050. [PubMed: 21411646]

Zeise ML, Espinoza J, Morales P, Nalli A. Interleukin-1beta does not increase synaptic inhibition in hippocampal CA3 pyramidal and dentate gyrus granule cells of the rat in vitro. Brain Res. 1997; 768:341-344. [PubMed: 9369335]

Zhang R, Sun L, Hayashi Y, Liu X, Koyama S, Wu Z, Nakanishi H. Acute p38-mediated inhibition of NMDA-induced outward currents in hippocampal CA1 neurons by interleukin-1beta. Neurobiol Dis. 2010; 38:68-77. [PubMed: 20060906] 
Zurolo E, Iyer A, Maroso M, Carbonell C, Anink JJ, Ravizza T, Fluiter K, Spliet GWM, van Rijen PC, Vezzani A, Aronica E. Activation of TLR, RAGE and HMGB1 signaling in malformations of cortical development. Brain. 2011; 134:1015-1032. [PubMed: 21414994] 


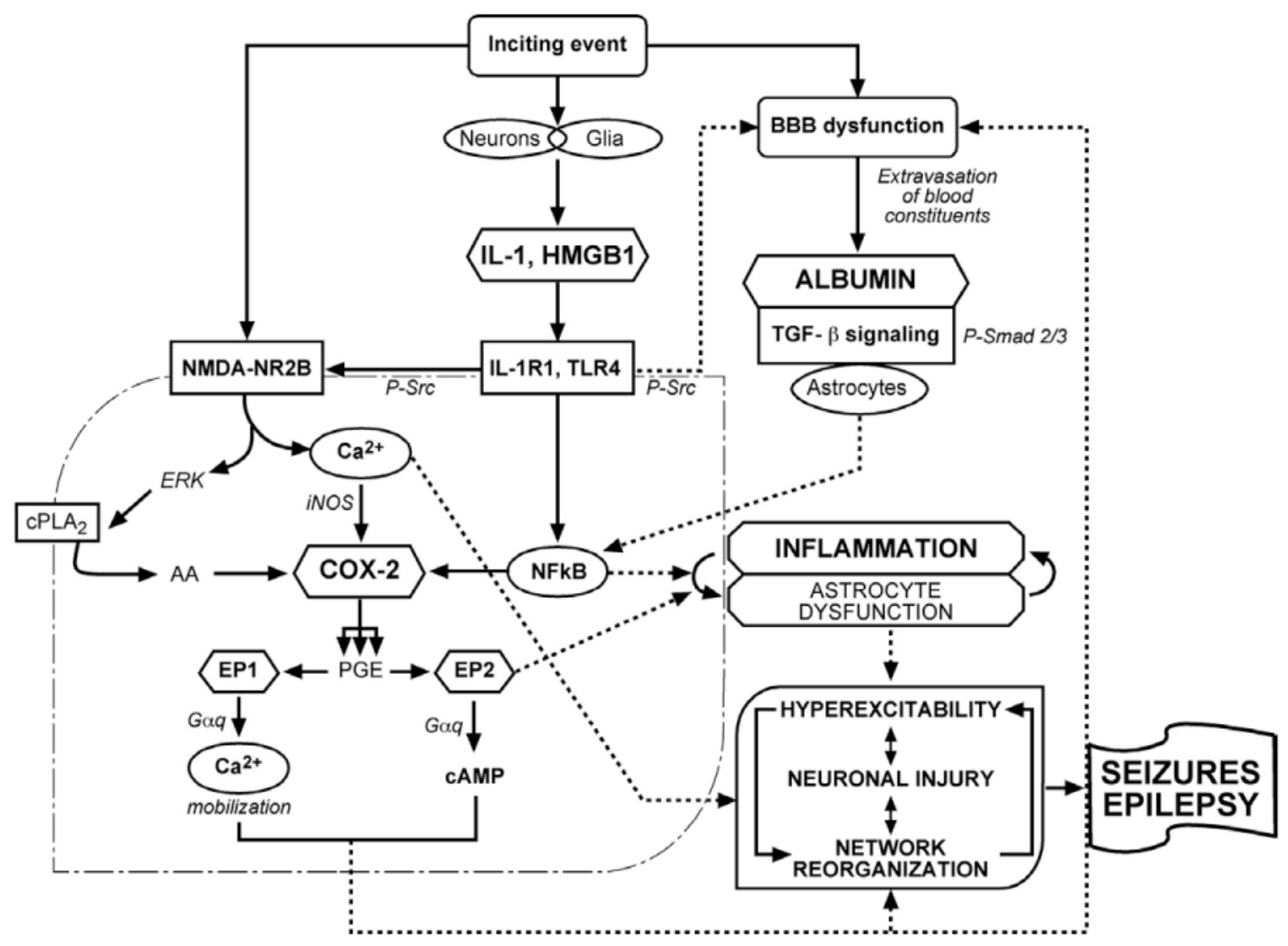

Figure 1. Schematic drawing of the pathophysiological cascade mediated by three key proinfammatory pathways activated in epilepsy: IL-1/TLR, COX-2 and TGF- $\beta$

An inciting event with epileptogenic properties (e.g. trauma, stroke, febrile seizures, status epilepticus, infection, gene mutation, etc) may lead to activation of microglia, astrocytes and neurons, and/or to BBB dysfunction, in the brain regions involved in the pathologic event. Primed cells release pro-infammatory cytokines such as IL-1 $\beta$, and danger signals such as HMGB1, thereby eliciting pro-inflammatory events in the target cells (i.e. neurons and glia) via autocrine or paracrine activation of IL-1/TLR signaling. Signaling activation in neurons results in a rapid increase of NMDA receptor $\mathrm{Ca}^{2+}$ conductance via Src mediated phosphorylation of the NR2B subunit, leading to increased intracellular $\mathrm{Ca}^{2+}$, which in turn results in pathologic outcomes such as neuronal hyperexcitability or injury, decreased seizure threshold, network reorganization. Src activation in endothelial cells may contribute to BBB breakdown. IL-1/TLR-mediated activation of the NFkB-depedent transcription of genes (including COX-2) contributes both to molecular and cellular changes involved in epileptogenesis, and to perpetuate brain inflammation. Inciting events may also lead to glutamate-mediated activation of NMDA receptors in neurons which in turn promotes COX-2 activation via inducible Nitric Oxyde (iNOS) and Phospholipase $\mathrm{A}_{2}$-mediated production of arachidonic acid (AA). Prostaglandin E (PGE) is produced which activates EP1 and EP2 receptors coupled to intracellular signaling involving $\mathrm{Ca}^{2+}$ mobilization from intracellular stores and cAMP production, respectively, also contributing to inflammation, $\mathrm{BBB}$ dysfunction and pathologic outcomes. $\mathrm{BBB}$ dysfunction resulting from the inciting event or from inflammation (IL-1/TLR, COX-2) in turn leads to albumin extravasation in brain parenchyma, and subsequent activation of TGF- $\beta$ signaling in astrocytes. This signaling promotes further inflammation by $\mathrm{NFkB}$ dependent gene transcription, to astrocitic dysfunction (i.e. decreased Kir4.1 and glutamate transporter) and pathologic outcomes. This 
chain of consequential or concomitant events give raise to neuronal network hyperexcitability, cell injury, and network reorganization which are then responsible for the onset of seizures and the development of epilepsy. 